Paper

\title{
The coiled Electric Double Layer Capacitors Formed with Carbon Nanotube
}

\section{CNT を添加した捲回型電気二重層キャパシタ（捲回型 EDLC）の開発}

\author{
Manabu IMANO \\ Department of Electrical \& Electronic Engineering, Tokai University , 1117 Kitakaname, Hiratsuka, \\ Kanagawa, 259-1292 Japan
}

TEL: x81-463-58-1211(EX.4023) FAX: x81-463-59-4014 e-mail: 8adpm005@mail.tokai-u.jp

\author{
Yoshiyuki SHOW \\ Department of Electrical \& Electronic Engineering, Tokai University , 1117 Kitakaname, Hiratsuka, \\ Kanagawa, 259-1292 Japan \\ TEL:x81-463-58-1211(EX.4023) FAX:x81-463-59-4014 e-mail: show@keyaki.cc.u-tokai.ac.jp \\ ( Received 29, January 2009 Accepted 16, March 2009)
}

The carbon nanotube (CNT) was added into polarizable electrode instead of the acetylene black (AB) as conducting material of the coiled EDLCs. The capacitance of the EDLCs with addition of the CNTs or the $\mathrm{ABs}$ are almost same value.The series resistance of CNT-added EDLCs is lower than that of AB by 30[\%]. Therefore, it is effective to add the CNTs into polarizable electrode as conducting material of the coiled EDLCs.

Keywords : The Coiled EDLCs, The CNT, The Series Resistance, The Capacitance

\section{INTRODUCTION}

電気二重層キャパシタ(EDLC)は、電解液に含まれる電 解質イオンが電極部分で吸脱着することにより蓄電を行 う蓄電デバイスである。EDLC の特徴は、一般的なコン デンサに比べ静電容量が大きく、急速充放電が可能で化 学反応を伴わないため、劣化が少なくサイクル寿命が長 い点である。このことから、電気自動車のアシスト電源 や太陽光発電システムのエネルギー貯蔵用電源などへの 応用が試みられており、次世代のクリーンな蓄電デバイ スとして期待されている。

EDLC は上記の特長の反面、電界コンデンサなどの他 のキャパシタに比べ直列抵抗成分の值が高いという久点 を持つ。直列抵抗成分は、充放電時に電気抵抗となりエ ネルギー損失を生じる。このことから、エネルギー損失 を抑えるために直列抵抗成分の值を低減する必要がある。

EDLC の等価回路は、Figure 1 に示すような直列抵抗成

SAS Award was given to this paper presented as Poster Presentation at the 2008 SAS Intelligent Symposium
分(Rs) と並列抵抗成分 $(\mathrm{Rp}) 、$ キャパシタ成分 $(\mathrm{C})$ の 3 つの 成分で表すことが出来る。直列抵抗成分 $(\mathrm{Rs})$ に電流が流 れると、電力が熱エネルギーに変換・消費されてエネル ギー損失となり蓄電効率を低下させてしまう。

これまでの本研究では、ボタン型EDLC の分極電極に 導電材として、電気伝導性に優れ、化学的に安定という 特長を持つカーボンナノチューブ(CNT)を添加すること により、従来のボタン型 EDLC よりも直列抵抗成分の值 を低減することができた。EDLC にはボタン型 EDLC と、 Figure 2 に示寸捲回型 EDLC の 2 種類がある。捲回型 EDLC は分極電極を薄膜化して金属箔と巻いた構造であ り、ボタン型EDLCに比べ直列抵抗成分が低いという特 徵を持っている。本研究では、分極電極に導電材として CNT を添加した捲回型 EDLC の作製と評価を行い、従来 よりも直列抵抗成分を低減した捲回型 EDLC の作製を試 みた。また、比較のために導電材として一般的に用いら れているアセチレンブラック $(\mathrm{AB})$ を添加した捲回型 EDLCの作製も試みた。 


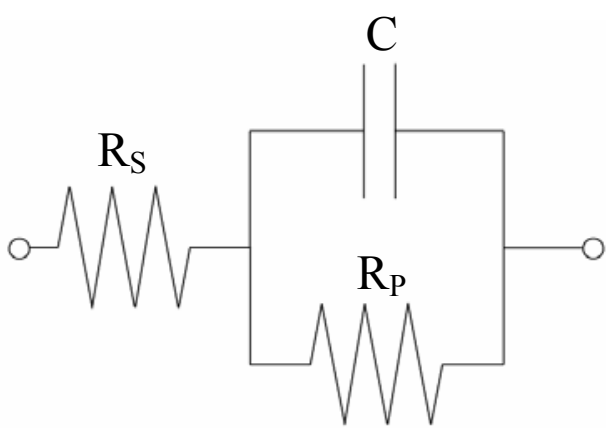

Figure 1. Equivalence Circuit of EDLC

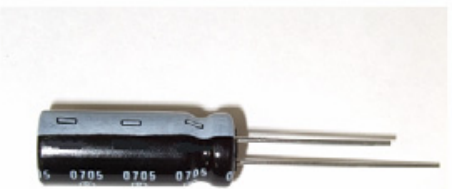

Figure 2. Coiled EDLC

\section{II.FABRICATION}

CNT または AB を添加した捲回型 EDLC を作製するた め、最初に捲回型 EDLC の分極電極材料の塗料化を行っ た。両極の作製に用いた材料は、N-メチル-2-ピロリドン (NMP)とポリフッ化ビニリデン (PVDF)/NMP 溶液、活性 炭、CNT/NMP 溶液、AB である。本研究で分極電極材料 として用いた活性炭及びCNTの電子顕微鏡写真を Figure 3 に示す。また比較のために用いた導電材の $\mathrm{AB}$ の電子 顕微鏡写真も Figure 3 に示す。

Figure 3(a)に活性炭の電子顕微鏡写真を示す。本研究で 用いた活性炭は、表面積が $2000\left[\mathrm{~m}^{2} / \mathrm{g}\right]$ 程度であり、粒径 が数 $[\mu \mathrm{m}]$ の粒状である。Figure 3(b)にCNTの電子顕微鏡 写真を示す。本研究で用いたCNTは、長さが $100[\mu \mathrm{m}]$ で多層のものである。Figure 3(c)にABの電子顕微鏡写真 を示す。ABは $50[\mathrm{~nm}]$ 程度の粒状である。同じ導電材と して用いているCNTと比較すると、両物質の直径は大差 は無いが、 $\mathrm{AB}$ の方は粒状なのに対し、CNTの方は 10000 程度の高いアスペクト比を有する繊維状である点で違い がある。

溶媒としてNMP とバインダーとしてPVDF がNMP に 溶解している PVDF/NMP 溶液、分極電極として活性炭 を用い、導電材として CNT が NMP に溶解している CNT/NMP 溶液、ABを用いた。

塗料は、重量比率で PVDF/NMP 溶液:NMP:活性炭の重
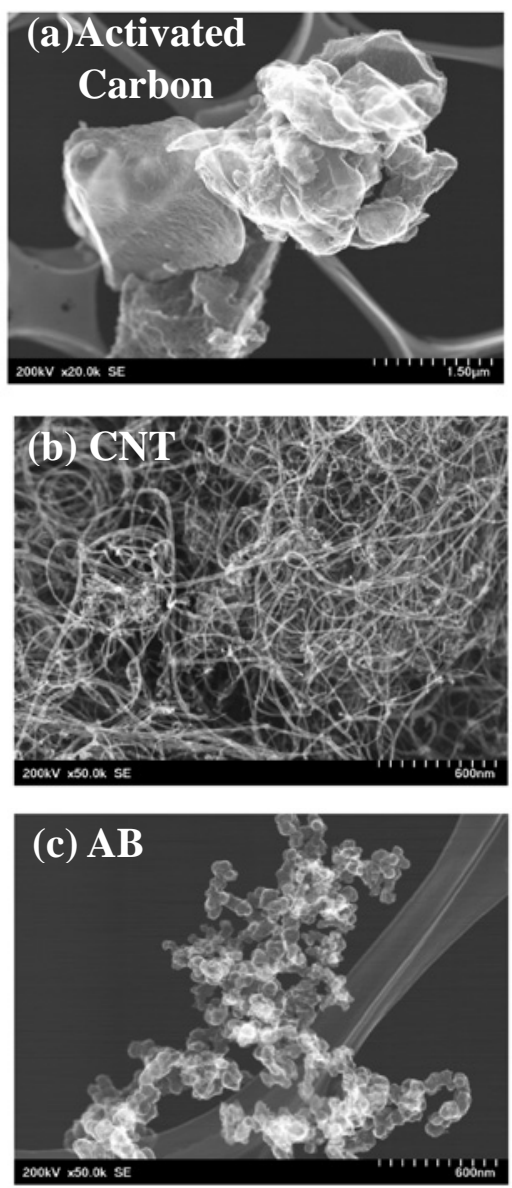

Figure 3. Scanning Electron Microscope (SEM) Photographs of Electrode materials (a) Activated Carbon, (b) CNT,(c)AB

量比が 10:71:20 とした。まず、スクリュー管に溶媒であ る NMP 及びバインダーとしての働きを持つPVDF を含 んだ PVDF/NMP 溶液を計り採った。その後、約 $45\left[{ }^{\circ} \mathrm{C}\right]$ の水を張った超音波洗浄機に入れ、ホモジナイザーを用 いて攪挥を $1[\mathrm{~min}]$ 行った。その後、超音波洗浄機での覺 找を $15[\mathrm{~min}]$ 行った。続いて、導電材である CNT を含ん だ CNT/NMP 溶液又は EDLC の一般的な導電材として用 いられる $\mathrm{AB}$ をスクリュー管に入れ、NMP と PVDF/NMP 溶液の攪拌手順と同様の手順で攪拌した。最後に、 $200\left[{ }^{\circ} \mathrm{C}\right] 、 1$ 時間の熱処理を行った活性炭をスクリュー管 へ入れ、NMP と PVDF/NMP 溶液の攪挥手順と同様の手 順で攪挥し、分極電極塗料を完成させた。分極電極塗料 をアルミ筞(厚さ $30[\mu \mathrm{m}]$ )上の面積 $1.0 \times 1.0[\mathrm{~cm}]$ の領域に 塗布し、110 $\left[{ }^{\circ} \mathrm{C}\right]$ 設定のオーブンで $30[\mathrm{~min}]$ 乾燥を行い、 Figure 4 に示すような電極箔を試作した。その後、分極 電極部分を有機系電解液で含浸し、次いでガラス板を用 いて Figure 5 に示すようなセルを作製した。 


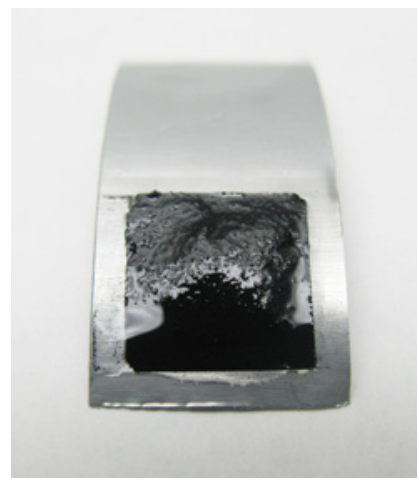

Figure 4. The Electrode Foil

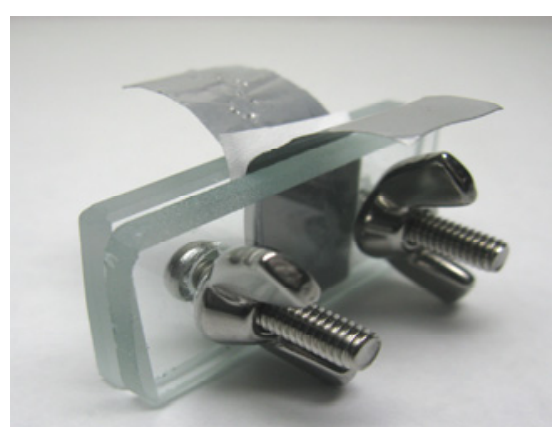

Figure 5. Assembled Cell

\section{III.MEASUREMENT}

本研究では、作製したセルの性能評価を行うため、充 放電試験を用いた。充放電試験は、EDLC に対して一定 の電流を加えて設定電圧まで充電を行い、満充電後、一 定の電流で放電を行う。この一連動作を繰り返して行い、 充電時の電圧と放電時の電圧の変化を測定するのが充放 電試験である。

設定電圧 $0.1 \sim 1.2[\mathrm{~V}]$ で充放電電流を $1[\mathrm{~mA}]$ と $5[\mathrm{~mA}]$ と して測定を行った。1[mA]は静電容量を測定するため、 また $5[\mathrm{~mA}]$ は直列抵抗成分を測定するために行った。充 電時は、1[mA]または $5[\mathrm{~mA}]$ の定電流で $0.1[\mathrm{~V}]$ から $1.2[\mathrm{~V}]$ まで充電を行った。放電時は、1 $[\mathrm{mA}]$ または $5[\mathrm{~mA}]$ の定 電流で $1.2[\mathrm{~V}]$ から $0.1[\mathrm{~V}]$ まで放電を行った。この充放電 サイクルを 1 サイクルとして、計 5 サイクルを連続的に 繰り返して測定を行った。また、CNT を添加したサンプ ルと $\mathrm{AB}$ を添加したサンプルを各 3 個ずつ作製して測定 を行った。

\section{RESULTS}

充放電試験で測定した、充放電時間 $\mathrm{t}[\mathrm{sec}]$ の変化に対す る充放電電圧 V[V]の変化を測定した結果を Figure 6 に示
し、グラフから算出した $\mathrm{AB}$ を添加したサンプル及び CNT を添加したサンプルの直列抵抗成分の值と静電容 量の值を Table 1 に示す。Figure 6 は CNT を添加した EDLC サンプル中の 1 つの充放電特性のグラフで、0.1[V]

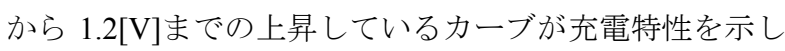
ており、1.2[V]から 0.1[V]までの下降しているカーブが 放電特性を示している。Figure 6 より充放電を繰り返し 行っていることが判ることから、キャパシタとして動作 していることがわかった。

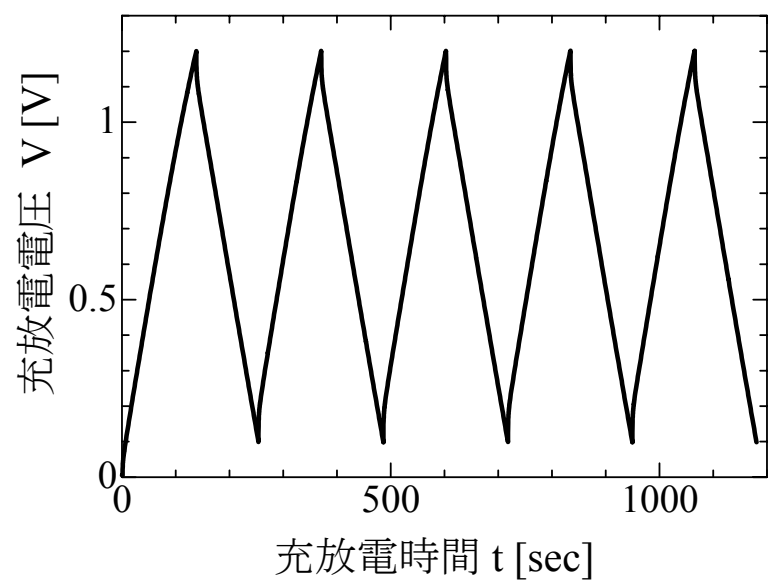

Figure 6. Resalt of Charge-DisCharge Measurement

また、Figure 6 のグラフから直列抵抗成分の值と静電 容量の值を求めた。まず静電容量は、充電特性を示すカ 一ブの傾きから求めることができる。しかし、実際に測 定した充電特性は、傾きが直線ではないため、前述の方 法では求められない。そこで、フィッティングという方 法を用いて求めた。フィッティングとは、EDLC の等価 回路(Figure 1)より 理論電圧式を求め、最小二乗法を用い て理論值と測定值を比較することにより求める方法であ る。Figure 1 の等価回路に定電流で充電を行った時、充 電時間に対する充電電圧は、

$$
\mathrm{V}=\mathrm{I} * \mathrm{R}_{\mathrm{S}}+\mathrm{I} * \mathrm{R}_{\mathrm{P}} *\left(1-\exp \left[-\mathrm{t} /\left(\mathrm{C} * \mathrm{R}_{\mathrm{P}}\right)\right]\right)[\mathrm{V}]
$$

と表すことができる。求めた電圧の式(1)から最小二乗法 を用いて、測定值のグラフのフィッティングを行い、充 放電を行った結果から求めたサンプルの静電容量は、 $\mathrm{AB}$ を添加した場合、0.520[F]であった。CNT を添加した場 合、0.433[F]であった。この結果から、CNT の分極電極 への添加による静電容量の増加は確認出来なかった。

直列抵抗成分は、充電特性を示したカーブで見られる 充電開始時の立ち上がり電圧から求めることができる。 立ち上がり電圧を $\mathrm{V}_{\mathrm{r}}[\mathrm{V}]$ 、充電電流を $\mathrm{I}[\mathrm{A}]$ の場合、直列抵 抗成分 $R_{S}$ は、近似的に 
$\mathrm{R}_{\mathrm{S}}=\mathrm{V}_{\mathrm{r}} / \mathrm{I}[\Omega]$

で求めることができる。

前述の方法より求めた直列抵抗成分は、 $\mathrm{AB}$ を添加し た場合、8.28[ $\Omega]$ であった。一方 CNT を添加した場合、 約 $5.99[\Omega]$ であった。CNT を添加したことで直列抵抗成 分は、 $\mathrm{AB}$ を添加した場合よりも約 $30[\%]$ 程度減少した。

$\mathrm{CNT}$ が $\mathrm{AB}$ より直列抵抗成分を低減させた要因として、 導電材である $\mathrm{CNT}$ と $\mathrm{AB}$ の形状の違いが考えられる。 Figure 7 に、分極電極内部において CNT の導電材として の働きをモデル化した図を示した。AB は粒径が $50[\mathrm{~nm}]$ 程度の粒状で粒径が数 $[\mu \mathrm{m}]$ の活性炭より数十分の 1 の 大きさである。このため、活性炭同士の隙間を埋める状 態で導電材として働いているものと考えられる。一方、 CNT は直径数 $[\mathrm{nm}]$ で長さ $100[\mu \mathrm{m}]$ の細長い繊維状をし ている。活性炭の粒径と比較して数十倍以上という長さ を持っている CNT は、一本でいくつもの活性炭間を結ぶ 電気的ネットワークを形成寸ることができると考えられ る。このことから、電気を流しやすくし、 $\mathrm{AB}$ を添加し たEDLCよりも分極電極の導電性が高くなったことによ り直列抵抗成分が低減したと考えられる。加えて、CNT の高い導電性という特徵が働いたことも直列抵抗成分を 低減できた要因として考えられる。

Table 1. The Capacitance and The Serise Resistance of the coiled EDLCs added the ABs of $5[\%]$ and added the CNTs of $5[\%]$.

\begin{tabular}{|c|c|c|}
\hline & $\begin{array}{c}\text { The } \\
\text { Capacitance[F] }\end{array}$ & $\begin{array}{c}\text { The Serise } \\
\text { Resistance }[\Omega]\end{array}$ \\
\hline $\mathrm{AB}$ & 0.520 & 8.28 \\
\hline $\mathrm{CNT}$ & 0.433 & 5.99 \\
\hline
\end{tabular}

\section{CONCLUSION}

本研究では、分極電極の導電材として CNTを添加した 捲回型 EDLC を作製し評価を行った。実験の結果より CNT を添加した場合、 $\mathrm{AB}$ を添加した場合よりも ESRを
約 30[\%]程度低減できることを確認した。また、CNTを 添加した場合と $\mathrm{AB}$ を添加した場合の静電容量への影響 は見られなかった。以上のことより、捲回型 EDLC の導 電材として CNT を用いることが有効であることがわか った。

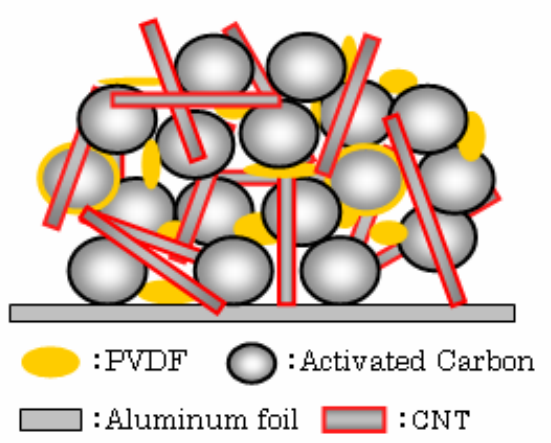

Figure 7. Model of Electrical Conduction Mechanism

\section{ACKNOWLEDGEMENTS}

本研究を行うにあたり,実験及びデータ処理を行う際、 快く協力してくださった先輩方、同輩方ならびに卒業研 究生諸氏に対して感謝致します。

本研究のために、EDLC 用アルミ箔を提供してくださ いましたエルナー株式会社、PVDF/NMP 溶液を提供して くださいました呉羽化学工業株式会社、CNT/NMP 溶液 を提供してくださいました大橋春日通商株式会社に深く 感謝いたします。

\section{REFERENCES}

${ }^{1}$ M.Okamura, Electric Double Layer Capacitors and Storage Devices, Nikkan Kogyo Shimbun Ltd.

2 N.Koyama, S.Sugawara, Polymer Battery, CMC Publishing Co., Ltd, pp.185-205 